\title{
On the Teaching of College English Listening from the Perspective of Holistic Education
}

\author{
Jianming Gong \\ School of Foreign Languages \\ Huanghe Science and Technology College \\ Zhengzhou, China
}

\begin{abstract}
Holistic education stresses comprehensive human development, and opposes the overstress of the skill-based education. It is essential to implement quality education which is important in guiding English listening teaching. Teachers in the university should recognize the problems existing in the current college English listening teaching and embrace the holistic educational philosophy. With holistic education at the core, a rational choice of teaching materials, a creation of simulated learning situations and a good master of pluralistic teaching modes will enable the college teachers to help the students obtain better skill and quality education.
\end{abstract}

Keywords—holistic education; college english listening; quality education

\section{INTRODUCTION}

Quality education is an important goal of University personnel training. In the twenty-first century, with the deepening of globalization the social development, new requirements have been drawn of the college students' English skill and quality and China's colleges and universities have ushered in a new era of education reform. English listening and speaking abilities, as the key communicative skills, are gaining more and more attention in teaching, and listening comprehension ability as a prerequisite for effective communication ability is regarded as the focus of the English teaching. The inefficient output in college English listening teaching drives reformers to start making multi-directional, multi-faceted overview of the current teaching and listening problems such as overstressing listening ability as an instrumental skill, and thus ignoring it as a language of humanity; emphasizing listening skills to from the teacher's viewpoint and thus neglecting the feedbacks of the students as learners. Currently, with knowledge and skill acquired within a "teacher-student" based educational mode, it's common to see educators ignoring the emotional interaction between with learners, weakening humanistic heritage features of the language, and emphasizing excessive expression of rationality in class teaching, all of which can undoubtedly lead to problems in learning. This "skills stressed, humanities neglected" way of organizing the class not only is difficult to enhance learners' listening skills, but also makes it impossible to achieve the teaching objectives of cultivating high-quality English talents. The holistic education philosophy which rose in the late seventies emphasizes comprehensive human development. It breaks the traditional in-class teaching disadvantages and has an important guiding significance in effective teaching English listening with better skill acquisition and quality education.

\section{THE IDEA Holistic EdUCATION AND ITS VIEWS}

Holistic education means comprehensive education. This idea of educating people can date back to western classical philosopher Aristotle's concept of liberal education, which holds that the purpose of education is to explore one's own inherent potential to achieve human development, emphasizing the importance of the individual in education. The modern sense of the concept of holistic education was proposed by the American scholar Ron Miller in the 1970s, and then quickly spread throughout the world. It has now developed into one of the most influential educational thoughts.

Holistic education was put forward, to a large part, by the impact of humanism education thought. It also takes in both the people-oriented and socially-oriented educational philosophies, emphasizing the unity of individual values and social values in the educational process to achieve overall human development. Holistic education aims to balance the excessive skill-centered education to enhance the overall quality of education, that is, education should not be limited to the acquisition of knowledge and skills, but also include a comprehensive development in the individuals' personal moral, emotional, thinking development.etc. The main views of the concept of holistic education can be summarized as.

- It stresses holistic thinking and the pursuit of the overall development of human beings. It holds that education should be more focused on the exploring of human potentials to encourage individual selfrealization, with special attention to enhancing the inherent qualities of the individual, such as morality, emotion, interest, spiritual and so on.

- With integrity as the theoretical starting point, while it holds great respect for the individuals, it also stresses the relativities and connectedness between things, and people. Therefore in learning theory it emphasizes interaction, connection and transformation, and promotes interdisciplinary interaction. With recognition of conventional teaching experience, it advocates pluralism and diversity in both learning and teaching. 
- It attaches great importance to the cultivation of learners' humanistic spirit. It emphasizes that education should train students to gain an edge of humanistic care, the right values and the ability of critical thinking on the surrounding spheres and the like. With the spiritual pursuit of education, it can be realized that learners can gain a more independent personality, raise more independent consciousness and develop a sense of world feelings.

\section{The CURRENT SituATION OF COLLEGE ENGLISH LISTENING TEACHING}

Over the past years, with the continuous progress of the reform of college English teaching, college English listening classes are gaining more and more time arrangements, getting better and better teaching equipments, and environmental conditions for listening practices for students are as well much better, however, with a survey of the recent years' listening scores taken from the national College English Test (Band Four), it can be seen that the improvement of students' listening ability is not obvious. Traditional classroom teaching content usually involves vocabulary for listening, background knowledge, listening skills, interpretations of listening materials, dialogue and passage listening exercises, and in this skill-centered arrangement the larger part of the classroom time is occupied by vocabulary, listening exercises and skill interpretations, leaving no room for the literariness part of the language. If we take many realistic factors into consideration(for example, high school English teaching generally does not pay attention to the listening exercises etc.), this teaching arrangement seems understandable. However, from the point of the second language acquisition theory and the psychology of learning, language learning is not only to impart knowledge and skills, non-verbal factors also play an important role in capacity-building, and that's what we are now missing in the listening classroom teaching. Way too much attention to language skills, and neglect the individual needs of the learner as "person" not only make teaching difficult to improve the learner's level of listening, but from a macro point of view make it difficult to achieve the ultimate goal of education - the overall quality enhancement of human beings. To fully realize quality education in listening class, in addition to the many language related problems, there are still more that need to be dealt with.

\section{A. Lack of Emotional Communication}

Listening process includes complex psychological feedback process. A lot of research shows that listening comprehension is mastery process, a process of overcoming both the language barriers and non-language barriers. Namely, the listening comprehension and learning process is not only influenced by the learner's own language level, but also affected by other factors such as psychologically. Excessive classroom teaching of listening comprehension skills and blind repeat of listening materials may arouse students rebellious psychology in learning, counter-act against the teachers original class arrangements and teaching intentions. This negative emotion is not only conducive to the learning process of listening comprehension, but can become a stumbling block greatly affecting the exertion of the learners' language levels. Let alone the improvement of language skills and the enhancement of quality education.

\section{B. Lack of Cultural Communication}

Language is an important carrier of cultural inheritance, and any form of language teaching activities should not ignore the importance of cultural education. Either the traditional Chinese culture or western foreign culture, should be an essential part of English listening teaching. National leaders in China far more than in a scenario emphasizes that education should absorb the excellent culture of the west, inherit and develop traditional culture of China. But now many teachers think that listening class means the mastering of listening skills, and that the purpose of education in listening is to understand class materials, achieve high scores in exams, and catch the meaning in talks. Because of the lack of the input of cultural elements in the listening practice, many students suffer from cultural aphasia. Not only their boundaries of knowledge is limited to a little western culture, but also it turns out to be difficult for them even to express their own Chinese culture in English. Let alone the cultural exchange and cultural output.

\section{Lack of Value Orientation}

Language is the carrier of culture and history, and it not only can convey different cultural information, but also it can serve as a communicator of value orientation of a people. This value orientation affects people's daily lives to a great extent, causing different peoples to think and behave in different ways. For example, in the 70s of the twentieth century the emergence of new words in English vocabulary, such as "herstory" "womankind", was a result of the western social feminist movement. Many of the newly coined words reflect the history and value of people's pursuit of equality between men and women. Whereas "the big man, little woman" in Chinese expression reflects the traditional values towards roles played by different genders. Although, due to the impact of globalization, the eastern and western values are becoming more compatible than ever, the function that traditional language bears as carrier of different modes of thinking and value orientation is a factor that needs to be taken into consideration in the process of cultivating high-quality talents for any type of language learning. What the present listening class lacks is the idea that runs through the whole class teaching activities to guide the learners with the right social values, cultivate them with the spirit of humanity, and make each of them become a whole person.

\section{The Teaching of College English Listening IN THE CONCEPT OF HOLISTIC EDUCATION}

Starting from the holistic education concept, teachers should not only study the teaching materials, but also pay attention to the development needs of learners as human beings, and deepen teaching reform in field of teaching philosophy, teaching mode, and nonverbal factors etc., enriching the class with knowledge and in the meantime developing the learner's comprehensive quality. 


\section{A. Train Teachers with Holistic Education Philosophy and Promote the Transformation of Teacher's Role}

Concept decides behavior, and the change in behavior begins with the change of concept. From the perspective of education, holistic education philosophy is the root of all teaching activities. And the improvement of teachers is the cornerstone of the classroom, Tan Min holds the view that a lot of problems in the development of university in the final analysis lies in the lagged development of teachers. So in teaching of college English listening, teachers should build up the idea of holistic education in the first place. A teacher of English listening course should strengthen self learning through various ways, with advanced concept to guide their own teaching practice, constantly update and improve their teaching level, cultivate the high-quality talents with both ability and political integrity.

Through learning holistic education concept and carrying it through the classroom, the teachers can better understand the uniqueness and inherent potentials of the students as individuals, timely adjust their roles in the teaching activities and positioning, break the traditional teacher's positioning in the teaching of listening course, and achieve equal relationship and mutual respect between teachers and students. Teachers should be the guide and facilitator, and pay attention to students' inner demand and emotional needs. Teachers should position themselves as the holistic concept of organizers and implementers, and thus help students to achieve the goal of allround development.

\section{B. Establish A Learner-Centered Teaching Mode and Pay Attention to Students' Individual Growth}

Holistic education holds that education should pay attention to the potential excavation and encourage selfrealization of the individual. The teachers' traditional role should be changed in the teaching of listening and at the same time student-centered mode of teaching should be built to pay attention to students' potential mining and the improvement of students' internal quality so that a new mode of cultivating talents can be reached where the learners can take the lead in learning and the teachers will take the role in coaching. Therefore teachers should do as follow. First, focus on the student's individuality demand, be good at digging the potential of students, treat students as independent beings with emotions, and care for the inner growth of the students. Second, focus on the emotional needs of the students, encourage them and affirm their academic gains, and eliminate their inner anxiety in listening process. Third, focus on the students' interest, discover their likings, and apply different teaching methods such as structuring simulated learning situation to cultivate their critical thinking abilities under different environment. Fourth, construct an equal teacher-student relationship with mutual respect to promote the communication between teachers and students in learning so that the students can better themselves both in knowledge and quality.

\section{Select High Quality Listening Materials and Create Good Listening Situation}

Ron Miller, advocate of holistic education, once pointed out that holistic education is to achieve a holistic development with the method of the humanities education. Holistic education does not deny the importance of knowledge. It emphasizes more on the training of students with humanistic spirit. It believes that knowledge derives from specific culture, and that there is connectivity between knowledge and environment, culture, and emotion etc. The present English listening class concentrates most of the time on skills training rather than quality education. Teachers teach in the same old mechanical way, repeating listening materials again and again so that students can find the correct answers. A lesson for listening has indeed turned into a lesson of test, which can be very difficult to achieve the goal of really improving students' listening ability.

From the connectivity advocated by holistic education, teachers should choose good listening materials, create various simulated learning situations in class, so that the students can achieve effective connection between the knowledge, skills of the language and ideological, cultural, moral environment in a familiar or lifelike context or reality. During teaching, appropriate use of cultural background and emotional education in the teaching elements, teachers can stimulate students' learning desire by connecting the unknown with the known, and thus cultivate the learners' critical thinking ability over moral, political, and cultural environments. Through this, teachers can also help students to get rid of their anxious mood and the passive language input way of learning, realize the students' self-actualization of listening study and at the same time achieve the target of cultivating humanistic spirit.

\section{Construct Multimodal Teaching Mode and Realize the Diversification of Teaching and Learning}

In the learning theory, holistic education emphasizes the diversity and diversification of learning. Listening serves as one of the means of transmitting information, however, the formation and application of this process is never a single modal form. For example, in daily communication, outside of listening, communication can be achieved through vision and touch, and other forms of modal. And in the teaching, background information given in the form of visual and touch modal during the pre-listening stage, auxiliary means such as video and pictures used during the while-listening stage, and oral expressions and presentations during the after-listening stage all virtually improve the learners' cognitive levels of the themes and materials and stimulate the learners' inner cognitive ability. This way of modal transformation employed in listening arrangement can enhance learners' degree of internalization of knowledge and hence transfer more input into absorption.

Therefore, the teaching of college English listening should pay attention to the construction of a multimodal listening class teaching mode. In the implementation of teaching, teachers should fully mobilize the learner's multimodal senses, achieving an integration of listening skills and listening content by using the combination of a variety of modals. It should be pointed out that, as a class of listening, the 
establishment of multimodal should always give priority to acoustic modal. Pictures, videos and other visual forms or modals are to be used to decompose the complexity of information in listening materials, enhance the understandable possibility of the information, and finally assist learners with integration and total understanding of the listening information. In the preparation and implementation of teaching, teachers should be in proper control of the use of other modals, avoid a certain teaching arrangements like visual information being greater than that of auditory information.

\section{CONCLUSION}

The teaching of college English listening is not isolated, one-way language skill training. As an important component of college English teaching, listening class cannot be limited to only a training class of listening skills, but the teachers should also pay more attention to learners' comprehensive needs as whole independent individuals. As educators, teachers should strike a balance between the instrumentalism and humanism of the English language, implement holistic education idea in the teaching, and achieve the aim of cultivating future talents with both practical skills and good quality.

\section{REFERENCES}

[1] Allwright R L. The Importance of Interaction in Classroom Language Learning[J]. Applied Linguistics, 1984(5).

[2] Barron A. Acquisition in interlanguage pragmatics: learning how to do things with words in a study abroad context[M]. Amsterdam/Philadelphia: John Benjamins, 2003.

[3] Flowerdew, J., and Miller, L. Second Language Listening[M]. Cambridge: Cambridge University Press, 2005.

[4] Gao Xinhua, Chen Wei. Study of Multidimensional Means in English Listening [J]. Journal of MuDanJiang College of Education, 2014(11).

[5] Miller J P. Holistic Curriculum [M]. Toronto: OISE Press, Inc., 1988.

[6] Tan Min, Fan Yihong. Analysis on the Modern Holistic Education Ideas in the Western World [J] Studies in Foreign Education, 2006(9).

[7] Wu Libao, Xie Anbang. Reform of Teaching and Learning of University in Holistic Education Perspective[J]. Modern College Education, 2008(1).

[8] Zeng Yuping. Pragmatic Competence Development of English Majors in the Concept of "Holistic Education" [J]. Survey of Education, 2015(29). 